\title{
EFFECTS OF GREEN IRON NANOPARTICLES ON BIOFILM-FORMING BACTERIA
}

\author{
MADHUMITA GHOSH DASTIDAR*, NIVEDITHA BS, POOJA R
}

Department of Microbiology, Vijaya College, Bengaluru, Karnataka, India. Email: madhumita.dastidar@gmail.com

\author{
Received: 01 March 2020, Revised and Accepted: 10 April 2020
}

\section{ABSTRACT}

Objective: The objective of this study was to observe the effects of iron nanoparticles (FeNPs) synthesized from plant source of biofilm-forming bacteria.

Methods: FeNPs were synthesized from Pongamia pinnata leaf extracts and it was characterized using ultraviolet-visible spectrophotometer, scanning electron microscopy (SEM), Fourier-transform infrared (FTIR) spectroscopy, and energy-dispersive X-ray analysis (EDAX). The synthesized FeNPs were evaluated against biofilm-forming Gram-negative Pseudomonas, sewage organisms, and Gram-positive hay Bacillus, Bacillus subtilis. These biofilm-forming microorganisms were evaluated for antibiotic sensitivity. The extracellular and intracellular proteins of biofilm-forming bacteria were estimated in the presence of FeNPs.

Results: All these biofilm-forming microorganisms were found to be antibiotic resistant. The green FeNPs showed potential antimicrobial effectiveness against hay Bacillus followed by Pseudomonas and sewage bacteria. These nanoparticles inhibited the intracellular protein formation more than extracellular proteins of biofilm-forming microorganisms.

Conclusions: It can be concluded that the FeNPs synthesized from plant sources were effectively inhibited the biofilm-forming microorganisms by obstructing the intracellular protein synthesis. These nanoparticles can be used as an eco-friendly, cost-effective, and alternative molecule to treat the antibiotic-resistant biofilm-forming microorganisms.

Keywords: Biofilm, Iron Nanoparticles, Scanning electron microscopy, Fourier transform infrared, Energy-dispersive X-ray analysis

(C) 2020 The Authors. Published by Innovare Academic Sciences Pvt Ltd. This is an open access article under the CC BY license (http://creativecommons. org/licenses/by/4. 0/) DOI: http://dx.doi.org/10.22159/ajpcr.2020.v13i6.37304

\section{INTRODUCTION}

Nanotechnology has emerged rapidly during the past few years in a broad range of product domains. Metal nanoparticles are attained a great importance due to their features such as catalytic, magnetic optical, and electrical properties [1]. Several nanoparticles, such as silver, copper, iron (Fe), and gold, have been explored so far. These metals are applied as antimicrobial agents for a long period of time, but antibiotics supersede them [2]. Application of metals of their nanoparticulate form is currently considered to resolve bacterial infections but has attracted scientific attention only over the past decade. Majority of nanoparticles are popular due to their characteristics high surface to volume ratio which makes these nanoparticles are effective against several microbes $[3,4]$. A high surface to volume ratio is generally accompanies by increased production of reactive oxygen species, including free radicals. These characteristics allow nanoparticles to interact closely with microbial cell wall and membranes, damage their internal structures, and inactivate bacteria [5,6]. The Fe as metal is as reactive in air as in water and in the form of nanoparticles it is more active. Moreover, the iron nanoparticles (FeNPs) are non-toxic.

The microbes when aggregated together and attached to the surfaces tightly it form the biofilm. These biofilms are strengthened further by extracellular polysaccharides release by the microbes. Biofilm-forming microorganisms are highly pathogenic and in environment, it causes several health-related hazards $[7,8]$. Researchers have shown that 60$80 \%$ of microbial infections are caused by bacteria grown as biofilm than free-floating bacteria [9].

Drug resistance microorganisms are a serious and increasing public health problem. New strategies for controlling bacterial activities are urgently needed and nanoparticles can be a very promising approach [10]. It is well established that metallic compounds can have antimicrobial activity. A research work had taken up on biosynthesis of plant-based FeNPs, isolation, and assessment of biofilm-producing microorganisms and to monitor the effect of FeNPs on these microorganisms [11]. This study is an attempt to evaluate the action of green FeNPs on biofilm-forming bacteria. It gives an insight into the applications of FeNPs as alternative therapeutic tool against biofilmforming microorganisms.

\section{METHODOLOGY}

\section{Isolation of the biofilm-forming bacteria}

The three different biofilm-forming bacteria, namely, Pseudomonas aeruginosa, Bacillus subtilis, and a consortium of sewage bacteria were collected and inoculated in the nutrient broth and incubated at room temperature for $48 \mathrm{~h}$. After microscopic observation, the bacteria were subculture in the nutrient broth throughout the experiments [12].

\section{Biofilm formation assay}

The sterilized coverslips were dipped into the respective bacterial culture media and then stained with one drop of crystal violet (CV) and observed for the biofilm formation under the microscope [13].

To determine the antibiotic resistance of biofilm-forming bacteria The three bacterial samples were inoculated to the Mueller-Hinton agar (MH agar). The multiple antibiotic discs were placed on the MH agar containing P. aeruginosa, B. subtilis, and sewage bacteria. The plates are incubated at $37^{\circ} \mathrm{C}$ for $48 \mathrm{~h}$ and measured the zone of inhibition.

\section{Preparation of FeNPs from plant extracts}

The leaves of Pongamia pinnata were collected. The leaves were cleaned with water and dried by spreading for 2 days. The dry leaves were crushed in pestle and mortar. A $25 \mathrm{~g}$ of dry P. pinnata leaf powder were taken in $500 \mathrm{ml}$ of distilled water and boiled for $5 \mathrm{~min}$. The extract was filtered with normal filter paper and then with Whatman filters paper. The leaf extract was obtained and was used for further experiments. 
Various concentrations of ferrous sulfate $\left(\mathrm{FeSO}_{4}\right)$ salt $(0.5 \mathrm{mg} / \mathrm{ml}$, $0.25 \mathrm{mg} / \mathrm{ml}$, and $0.125 \mathrm{mg} / \mathrm{ml}$ ) were prepared in $10 \mathrm{ml}$ of leaf extract and incubated it at $37^{\circ} \mathrm{C}$ for $48 \mathrm{~h}$. The solution was centrifuged at $10,000 \mathrm{rpm}$ for $5 \mathrm{~min}$ and the supernatant was decanted, the precipitate was washed in distilled water. The precipitate was centrifuged at $10,000 \mathrm{rpm}$ for $5 \mathrm{~min}$ and decants the supernatant. The precipitate was dried and stored for analysis. This purified FeNPs were analyzed for scanning electron microscopy (SEM), energy-dispersive X-ray analysis (EDAX), and Fourier transform infrared (FTIR) analysis [14]

\section{Analysis of FeNPs}

SEM

SEM gives morphological examination with direct visualization. For sampling of SEM, the nanoparticles are dried into powder. The powder in small quantity was placed on a sample holder and then coated with gold as conductive metal. Next, the sample was scanned with a beam of electrons. The characterization of molecules was done from secondary electrons emitted from sample surface.

\section{EDAX spectroscopy}

To gain further insight into the features of the FeNPs, analysis of the sample was performed using EDAX techniques.

\section{FTIR spectroscopy}

The transmission spectra for the nanoparticles are obtained by the formation of thin, transparent potassium bromide $(\mathrm{KBr})$ pellets containing $0.1-1 \%$ sample was mixed with $200-250 \mathrm{mg}$ of $\mathrm{KBr}$. The $\mathrm{KBr}$ mixtures were placed in a vacuum line overnight before pellet formation, and the pellets were again placed in the vacuum line before use. The transmission spectra were obtained after purging in dry air and background corrected relative to a reference blank sample (KBr). With the application of modern software tools, quantitative analysis of the nanoparticles can be completed.

\section{Treatment of FeNPs with biofilm-forming microorganisms}

Overnight culture of biofilm-forming microorganisms $(1 \mathrm{ml})$ was incubated with FeNPs $(100 \mu \mathrm{l})$ for $24 \mathrm{~h}$ at $37^{\circ} \mathrm{C}$. After incubation, optical density was determined at $600 \mathrm{~nm}$.

Protein estimation of biofilm-forming bacteria treated with FeNPs The ELISA plate was inoculated with $100 \mu \mathrm{l}$ of overnight culture of biofilm-forming bacteria and $10 \mu \mathrm{l}$ of nanoparticles. Overnight incubation at $37^{\circ} \mathrm{C}$ was done. The protein was estimated by Lowry's method in control and treated wells [15].

\section{RESULTS AND DISCUSSION}

\section{Isolation of the biofilm-forming bacteria}

To observe biofilm production potential of bacterial isolates, the CV assay is commonly used. This assay is preferred due to its simplicity, reliability, and rapidity. With this assay, isolates can be categorized as high, moderate, or non-biofilm producers. The formation of biofilm comprises adsorption of macro- and micro-molecules followed by bacterial adhesion to the surface and biofilm maturation and colony formation. The $24 \mathrm{~h}$ incubation time helps in biofilm to be maturated and improved adhesion of biofilm on surfaces [16]. P. aeruginosa, B. subtilis, and sewage bacteria showed the initiation of biofilm formation after 24 h (Fig. 1). After $48 \mathrm{~h}$ under $\times 100$, all three isolates showed aggregated mass (Fig. 2). The biofilm grown toward center was more than periphery which avoids the false artifacts of "Edge Effect" phenomenon also [17]. $\mathrm{CV}$ is a basic dye that binds non-specifically to negatively charged surface molecules such as polysaccharides and DNA in the extracellular matrix. Because it binds cells as well as matrix components, it is generally used to evaluate biofilm biomass in toto. Repeated experiments showed that these three microorganisms were biofilm producers.

Determination of antibiotic resistance of biofilm-forming bacteria Biofilms provide the protection to the microorganism by blocking the access of bacterial biofilm communities from antibiotics. Sewage bacteria

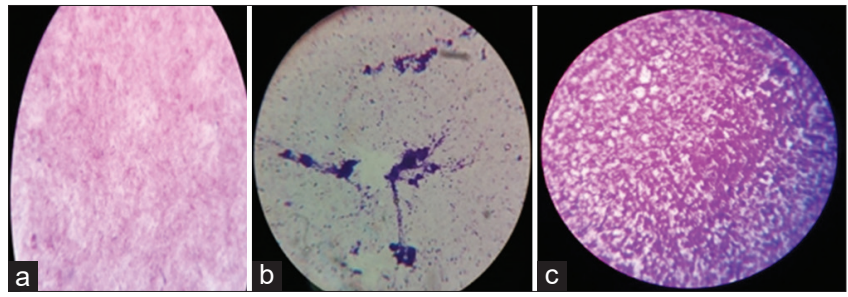

Fig. 1: (a-c) Biofilm formation after $24 \mathrm{~h}$ under $\times 100$

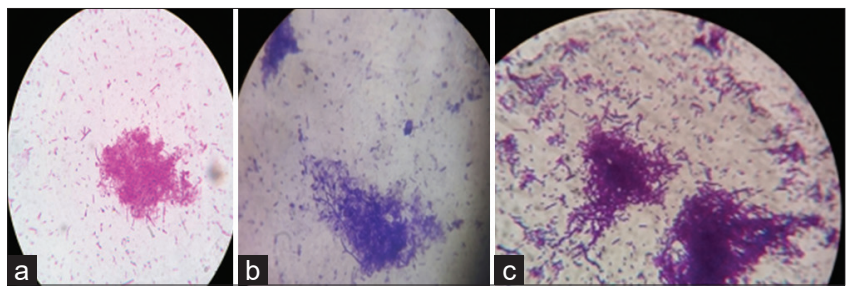

Fig. 2: Biofilm formation after $48 \mathrm{~h}$ under $\times 100$. (a) Pseudomonas aeruginosa, (b) Bacillus subtilis, (c) sewage bacteria

were found to be more antibiotic resistant than Pseudomonas (Table 1). The sewage bacteria revealed resistance to $67 \%$ of the antibiotics used in this experiment, whereas Pseudomonas bacteria showed 33\% resistant. Biofilms are associated with an emergence of antibioticresistant bacteria probably because the extracellular polysaccharides which released by biofilm bacteria act as shield to prevent the entry of antibiotics. The literature said that the classes of antibiotics that are hydrophilic and positively charged, such as aminoglycosides, are more obstructed than others [18]. Pseudomonas was found to be sensitive to the antibiotics amikacin, ciprofloxacin, gentamicin, cefoperazone, lomefloxacin, and ceptazidime. Chemically, amikacin and gentamycin are aminoglycosides; ciprofloxacin and lomefloxacin are fluoroquinolones, whereas cefoperazone and ceptazidime are cephalosporins class of antibiotics. The sewage bacteria showed sensitivity toward ciprofloxacin, gentamicin, lomefloxacin, and ceptazidime. Sewage bacteria being consortia of microorganisms showed greater resistance than Pseudomonas. These bacteria when present in a group were great competitors and therefore showed more resistance than individuals.

B. subtilis showed resistant toward majority of antibiotics (Table 2). These biofilm-forming bacteria have gained resistance for most of the antibiotics except cefuroxime, roxithromycin, and cefadroxil. Cefuroxime is the second-generation and cefadroxil is the firstgeneration cephalosporin antibiotic. Roxithromycin is a semisynthetic advanced generation macrolide antibiotic. The Gram-positive, spore former motile bacterium is a model organism to study biofilm formation. These bacteria are aerobes and form white pellicle on the surface of liquid medium. B. subtilis produces a wide array of antibiotics. It was reported that some of these antibiotics are non-ribosomal peptides such as surfactin, bacillaene, fengycin, iturin, and bacilysin which these bacteria use it for their survival in natural environment. B. subtilis produces some ribosomal synthesized peptide antibiotics, such as bacteriocins and other protein-derived toxins, which are generally effective against genetically similar bacteria and present in similar ecological niches [19]. B. subtilis showed $62 \%$ antibiotic resistance and intermediate toward cefadroxil and roxithromycin.

\section{Preparation of FeNPs from plant extracts}

After the addition of $\mathrm{FeSO}_{4}$ salt in the leaf extracts of $P$. pinnata, the color of the solution changes from faint yellow to green indicating the synthesis of FeNPs in the aqueous medium. These solutions were further analyzed for nanoparticles production.

\section{Analysis of FeNPs}

The EDAX profile of FeNPs showed the strong signal of the Fe atom indicates the crystalline property. The EDAX spectrum showed the 
Table 1: Antibiotic sensitivity of pseudomonas and sewage bacteria

\begin{tabular}{|c|c|c|c|c|c|c|c|}
\hline \multirow[t]{2}{*}{ Antibiotic } & \multirow{2}{*}{$\begin{array}{l}\text { Zone of inhibition ( } \mathrm{mm} \text { ) } \\
\text { Pseudomonas aeruginosa }\end{array}$} & \multirow{2}{*}{$\begin{array}{l}\text { Zone of inhibition }(\mathrm{mm}) \\
\text { Sewage bacteria }\end{array}$} & \multirow[t]{2}{*}{$\mathbf{S} / \mathbf{I} / \mathbf{R}$} & \multirow[t]{2}{*}{ Strength (mcg) } & \multicolumn{3}{|c|}{ Reference antibiotic (zone of inhibition) } \\
\hline & & & & & $\mathbf{R}$ & I & $\mathbf{S}$ \\
\hline An & $30 \pm 0.02(S)$ & $08 \pm 0.01(\mathrm{R})$ & $\mathrm{S}$ & 30 & $\leq 14$ & $15-16$ & $\geq 17$ \\
\hline $\mathrm{Cd}$ & $0 \pm 0.0(\mathrm{R})$ & $3 \pm 0.01(\mathrm{R})$ & $\mathrm{R}$ & 30 & $\leq 14$ & $15-17$ & $\geq 18$ \\
\hline Sf & $20 \pm 0.02(\mathrm{I})$ & $0 \pm 0.0(\mathrm{R})$ & $\mathrm{I} / \mathrm{R}$ & 5 & $\leq 15$ & $16-20$ & $\geq 21$ \\
\hline Ctx & $19 \pm 0.01(\mathrm{R})$ & $13 \pm 0.01(\mathrm{R})$ & $\mathrm{R}$ & 30 & $\leq 13$ & $14-20$ & $\geq 21$ \\
\hline Cip & $27 \pm 0.03(S)$ & $24 \pm 0.02(S)$ & $\mathrm{S}$ & 5 & $\leq 15$ & $16-20$ & $\geq 21$ \\
\hline $\mathrm{G}^{*}$ & $20 \pm 0.02(S)$ & $20 \pm 0.02(S)$ & $\mathrm{S}$ & 10 & $\leq 12$ & $13-14$ & $\geq 15$ \\
\hline Cf & $0 \pm 0.00(\mathrm{R})$ & $0 \pm 0.0(\mathrm{R})$ & $\mathrm{R}$ & 30 & $\leq 14$ & $15-22$ & $\geq 23$ \\
\hline Cfp & $24 \pm 0.03(S)$ & $7 \pm 0.01(\mathrm{R})$ & $\mathrm{S} / \mathrm{R}$ & 75 & $\leq 15$ & $16-20$ & $\geq 21$ \\
\hline $\mathrm{Lm}$ & $24 \pm 0.02(\mathrm{~S})$ & $26 \pm 0.02(S)$ & S & 5 & $\leq 18$ & $19-21$ & $\geq 22$ \\
\hline Ampicillin+Slb & $0 \pm 0.0(R)$ & $0 \pm 0.0(\mathrm{R})$ & $\mathrm{R}$ & 25 & $\leq 13$ & $14-16$ & $\geq 17$ \\
\hline $\mathrm{Cpz}$ & $24 \pm 0.04(\mathrm{~S})$ & $20 \pm 0.03(S)$ & $\mathrm{S}$ & 20 & $\leq 14$ & $15-17$ & $\geq 18$ \\
\hline
\end{tabular}

*Antibiotic disk diffusion method on MH agar and the zone of clearance was measured after the incubation period. Values are presented as mean \pm SD of the three triplicates of the experiments. SD: Standard deviation, S: Sensitive, I: Intermediate, R: Resistance. An: Amikacin, Net: Netilmicin, Cd: Cefadroxil, Sf: Sparfloxacin, Ctx: Ceftriaxone, Cip: Ciprofloxacin, G: Gentamycin, Cf: Cefotaxime, Cfp: Cefoperazone, Lm: Lomefloxacin, Slb: Sulbactam, Cpz: Ceptazidine

Table 2: Antibiotic sensitivity of Bacillus subtilis

\begin{tabular}{|c|c|c|c|c|c|c|}
\hline \multirow[t]{2}{*}{ Antibiotic } & \multirow[t]{2}{*}{ Zone of inhibition (mm) } & \multirow[t]{2}{*}{$\mathbf{S} / \mathbf{I} / \mathbf{R}$} & \multirow[t]{2}{*}{ Strength (mcg) } & \multicolumn{3}{|c|}{ Reference antibiotic (zone of inhibition) } \\
\hline & & & & $\mathbf{R}$ & I & $S$ \\
\hline An & $23 \pm 0.03$ & $S$ & 30 & $\leq 14$ & $15-16$ & $\geq 17$ \\
\hline Cip & $28 \pm 0.03$ & S & 5 & $\leq 15$ & $16-20$ & $\geq 21$ \\
\hline CLR & $0 \pm 0.00$ & $\mathrm{R}$ & 15 & $\leq 13$ & $14-17$ & $\geq 18$ \\
\hline Cf & $0 \pm 0.00$ & $\mathrm{R}$ & 30 & $\leq 14$ & $15-22$ & $\geq 23$ \\
\hline $\mathrm{Sf}$ & $10 \pm 0.01$ & $\mathrm{R}$ & 5 & $\leq 15$ & $16-20$ & $\geq 21$ \\
\hline $\mathrm{CR}$ & $8 \pm 0.01$ & $\mathrm{R}$ & 30 & $\leq 13$ & $14-17$ & $\geq 18$ \\
\hline Cfp & $7 \pm 0.01$ & $\mathrm{R}$ & 75 & $\leq 15$ & $16-20$ & $\geq 21$ \\
\hline ACX & $0 \pm 0.00$ & $\mathrm{R}$ & 20 & $\leq 23$ & $24-27$ & $\geq 28$ \\
\hline $\mathrm{Cd}$ & $15 \pm 0.03$ & I & 30 & $\leq 14$ & $15-17$ & $\geq 18$ \\
\hline $\mathrm{RX}$ & $15 \pm 0.03$ & I & 15 & $\leq 13$ & $14-17$ & $\geq 18$ \\
\hline G & $0 \pm 0.00$ & $\mathrm{R}$ & 10 & $\leq 12$ & $13-14$ & $\geq 15$ \\
\hline AZ & $0 \pm 0.00$ & $\mathrm{R}$ & 15 & $\leq 13$ & $14-17$ & $\geq 18$ \\
\hline
\end{tabular}

Antibiotic disk diffusion method on MH agar and the zone of clearance was measured after the incubation period. Values are presented as mean \pm SD of the three triplicates of the experiments. SD: Standard deviation, S: Sensitive, I: Intermediate, R: Resistance. AN: Amikacin, Cip: Ciprofloxacin, CLR: Clarithromycin, Cf: Cefotaxime, Sf: Sparfloxacin, CR: Cefuroxime, Cfp: Cefoperazone, ACX: Ampiclox, Cd: Cefadroxil, RX: Roxithromycin, G: Gentamycin, AZ: Azithromycin

elemental profile of FeNPs, primarily composed of C, O, S, and Fe. The C and $\mathrm{O}$ are mainly from the compounds present in plant extracts, while $\mathrm{Fe}$ and $\mathrm{S}$ from the $\mathrm{FeSO}_{4}$ precursor. The sharp peak showed FeNPs production and percentage estimated to be $17.3 \%$ (Fig. 3).

FTIR spectrophotometric analysis of FeNPs

FTIR identifies that various groups involve for reduction and capping of nanoparticles. FTIR spectroscopy measures the spectral peaks of functional groups. FeNPs spectra and absorbance bands have been observed in the region of 3419.28, 2110.30, 1645.46, 1011.64, 951.82, and $788.40 \mathrm{~cm}^{-1}$ which confirmed $\mathrm{O}-\mathrm{H}$ group, alkyne group, amide ( $C=0$ ), ether, alkene, and alkyl halide, respectively. Furthermore, adsorption bands at around $581 \mathrm{~cm}^{-1}$ correspond to the formation of FeNPs. This result indicates that the hydroxyl and phenolic groups are the active sites during the synthesis, and hence, the $\mathrm{O}-\mathrm{H}$ and $\mathrm{C}=\mathrm{C}$ groups are involved in the reduction of $\mathrm{FeSO}_{4}$ into FeNPs (Fig. 4)

\section{SEM of FeNPs}

FeNPs were examined through SEM analysis to evaluate their morphology and their degree of dispersion. It indicated that FeNPs were agglomerated because of the adhesive nature. The morphology of SEM found to be irregular spherical structures. Average diameter of FeNPs was found to be about $85 \mathrm{~nm}$ (Fig. $5 \mathrm{a}$ and b).

\section{Treatment of FeNPs with biofilm-forming microorganisms}

The positively charged NPs easily get attached to the surface of negatively charged bacterial cells that result in rupture of cell wall followed by cell death [20]. The lowest growth of P. aeruginosa biofilm bacteria was observed in the presence of FeNPs produced from $0.25 \mathrm{mg} / \mathrm{ml}$ of $\mathrm{FeSO}_{4}$ salt, whereas FeNPs of $0.5 \mathrm{mg} / \mathrm{ml}$ of $\mathrm{FeSO}_{4}$ showed marginal inhibition when compared with control and FeNPs of $0.125 \mathrm{mg} / \mathrm{ml}$ of $\mathrm{FeSO}_{4}$ had lesser effect on growth of these microorganisms (Fig. 6). The antimicrobial activities of FeNPs on B. subtilis showed with both $0.25 \mathrm{mg} / \mathrm{ml}$ and $0.5 \mathrm{mg} / \mathrm{ml} \mathrm{FeSO}{ }_{4}$ salt producing nanoparticles. The sewage bacteria were not inhibited much with FeNPs with respect to control. Therefore, this study revealed that the FeNPs when produced from aqueous extract of leaves of $P$. pinnata, it could effectively inhibit the biofilm-forming P. aeruginosa and B. subtilis. This study of antimicrobial effect was according to the report given in literature [21]. Probably with $0.125 \mathrm{mg} / \mathrm{ml}$ of salt concentration could not be converted by leaf extracts into effective nanoparticles, and therefore, the antimicrobial activity was insignificant with respect to both Gram-positive and Gram-negative bacteria. However, the effect of $0.25 \mathrm{mg} / \mathrm{ml}$ of salt concentration FeNPs showed better inhibitory effect which could be due to smaller nanoparticles which has better penetration and accumulation through bacterial cell wall.

Protein estimation of biofilm-forming bacteria treated with FeNPs The extracellular and intracellular protein concentration when measured in the presence of FeNPs, it was observed that the intracellular protein was greatly reduced in P. aeruginosa and B. subtilis compared to control (Fig. 7). In both the situations, extracellular protein concentration was increased in the presence of FeNPs. The study of both extracellular and intracellular protein concentration and FeNPs effect was reported $1^{\text {st }}$ time in this work. Probably, the FeNPs bind to the cell wall of both Gram-positive and Gram-negative bacteria which, in 


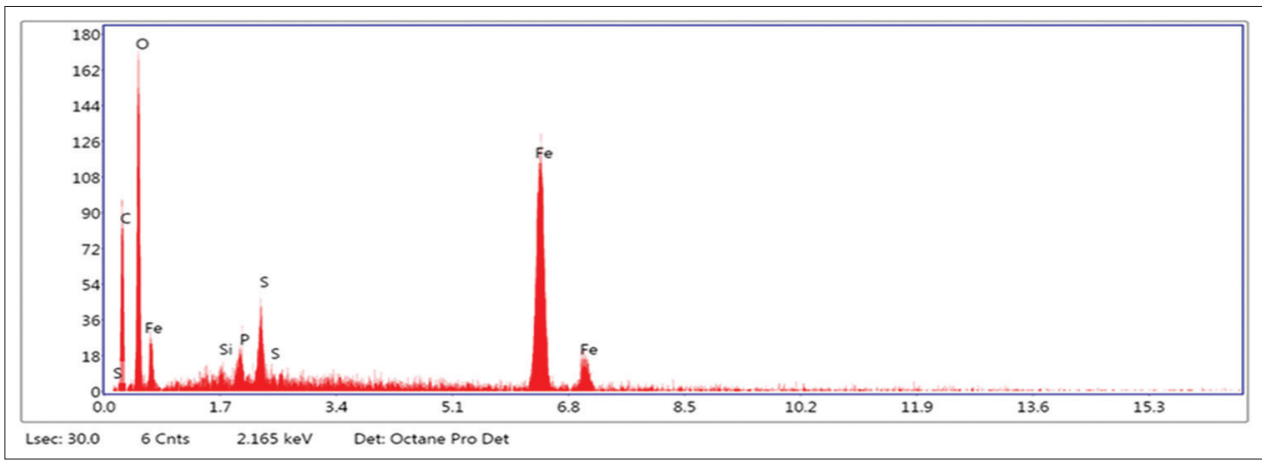

Fig. 3: Energy-dispersive analysis of X-ray diffraction spectroscopy of FeNPs

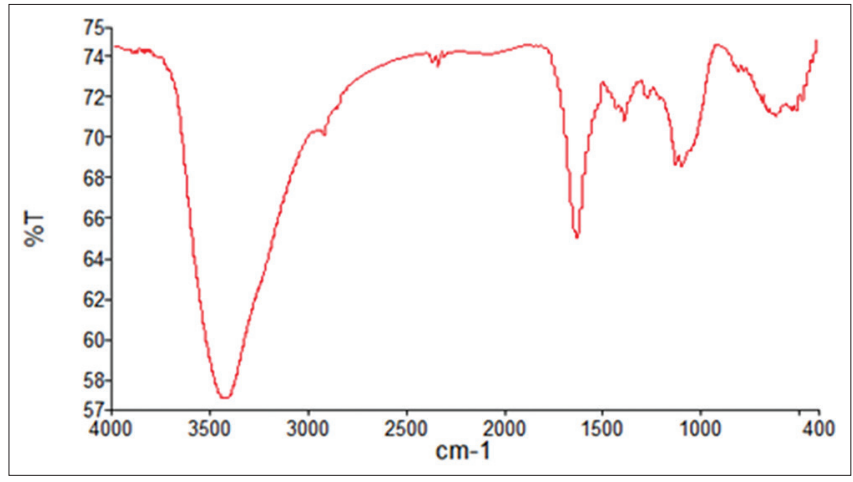

Fig. 4: Fourier transform infrared spectrophotometer of FeNPs

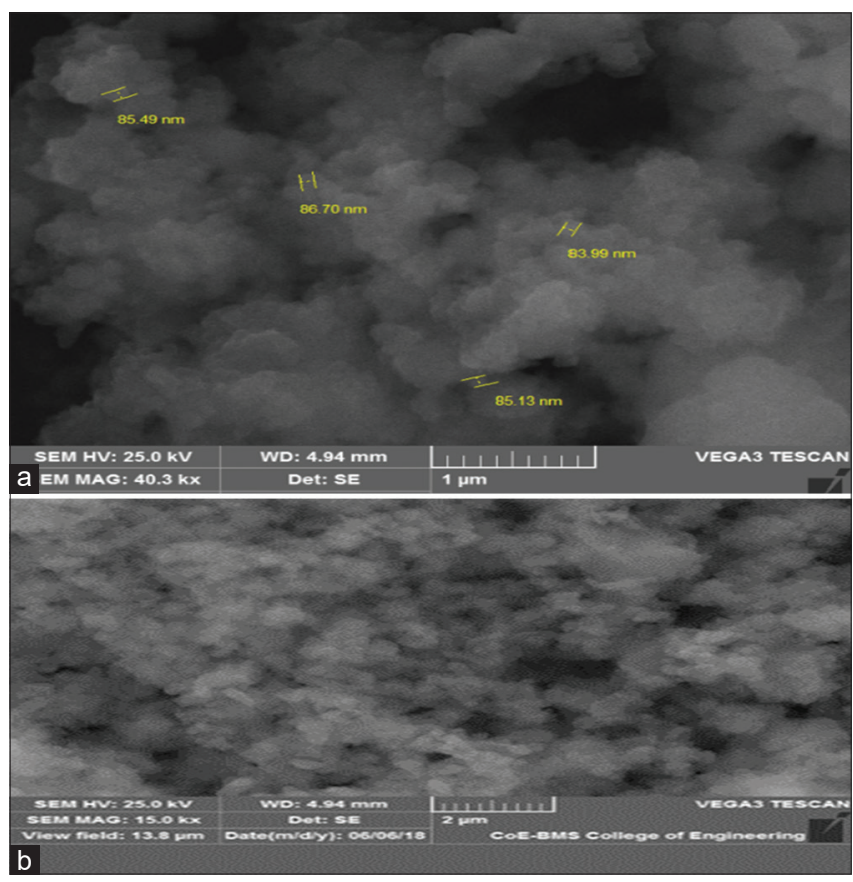

Fig. 5: Scanning electron microscopy (SEM) of FeNPs (a) the size ranges of nanoparticles at $40.3 \mathrm{kx}$. SEM of FeNPs (b) at the magnification of $15.0 \mathrm{kx}$

turn, increased uptake of ions lead to intracellular damage. The binding capacity of FeNPs to Gram-negative cell wall is more due to extra lipopolysaccharide layer and therefore more leakage of extracellular proteins. Although the exact mechanism of the action of FeNPs is not known, probably, smaller molecules of FeNPs penetrate better through cell wall and cell membrane of bacteria and inhibit translation process of bacterial cell [22].

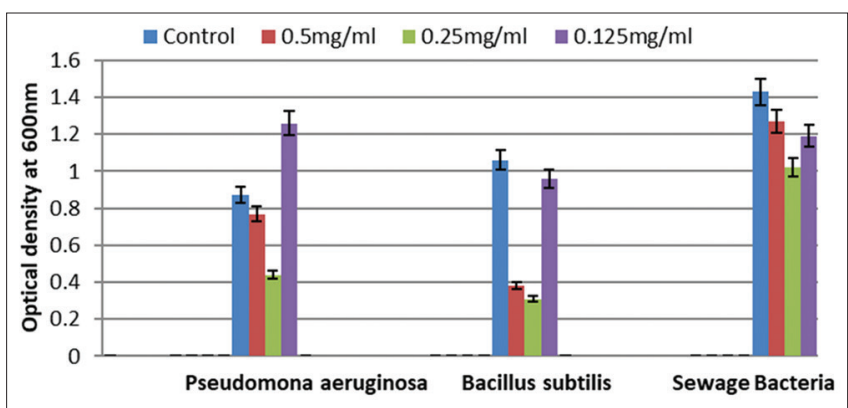

Fig. 6: Effect of FeNPs on biofilm bacteria. *All the data were reported as mean standard error of three replicates $(n=3)$. Control: Only bacteria OD600 of 1.0 is roughly $3 \times 10^{7}$ cells $/ \mathrm{ml}$

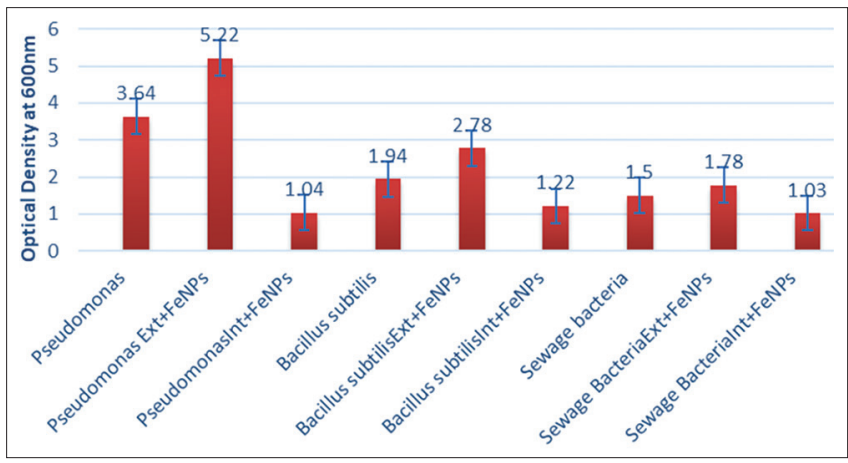

Fig. 7: Effect of FeNPs on protein concentration of biofilm-forming bacteria. *All the data were reported as mean \pm standard error of three replicates $(n=3)$. Control: Only bacteria $0 D 600$ of 1.0 is roughly $3 \times 10^{7}$ cells $/ \mathrm{ml}$

\section{CONCLUSIONS}

An eco-friendly and economic green FeNPs were synthesized from aqueous extracts of $P$. pinnata. In this study, the biofilm-forming bacteria, $P$. aeruginosa, B. subtilis, and sewage bacteria, were isolated and identified as resistant to multiple antibiotics. The green FeNPs efficiently inhibited the growth of these biofilm-forming bacteria. These nanoparticles showed inhibitory effect on protein synthesis of bacteria, making these nanoparticles as an effective molecule to treat biofilmforming microorganisms. The exact mechanism on protein synthesis should be elaborated in future. Finally, this is a vital area of research that deserves our attention because of its potential application against multidrug-resistant microorganisms.

\section{AUTHORS' CONTRIBUTIONS}

This research work has carried out in the Department of Microbiology laboratory, Vijaya College, India. The EDAX, FTIR, and SEM work has carried out in BMS Engineering College, Bengaluru. 


\section{CONFLICTS OF INTEREST STATEMENT}

The authors declared no conflicts of interest.

\section{FUNDING}

Nil.

\section{REFERENCES}

1. Seil JT, Webster TJ. Antimicrobial applications of nanotechnology: Methods and literature. Int J Nanomedicine 2012;7:2767-81.

2. Koper OB, Klabunde JS, Marchin GL, Klabunde KJ, Stoimenov P, Bohra L. Nanoscale powders and formulations with biocidal activity toward spores and vegetative cells of bacillus species, viruses, and toxins. Curr Microbiol 2002;44:49-55.

3. Kobayashi K, Ikemoto Y. Biofilm-associated toxin and extracellular protease cooperatively suppress competitors in Bacillus subtilis biofilms. PLoS Genet 2019;15:e1008232.

4. Maice F, María C, Carlos C. Synthesis of iron nanoparticles from aqueous extract of Eucalyptus Robusta Sm and evaluation of antioxidant and antimicrobial activity. Mater Sci Energy Technol 2020;3:97-103.

5. Kavitha KS, Syed B, Rakshith D, Kavitha HU, Rao HC, Harini B, et al. Plants as green source towards synthesis of nanoparticles. Int Res J Biol Sci 2013;2:66-76

6. Kirubha A. Green synthesis of silver nanoparticles using Cissus quadrangularis plant extract and their antibacterial activity. Int $\mathrm{J}$ Nanomater Biostruct 2012;2:30-3.

7. Donlan RM, Costerton JW. Biofilms: Survival mechanisms of clinically relevant microorganisms. Clin Microbiol Rev 2002;15:167.

8. McLean RJ, Bates CL, Barnes MB, McGowin CL. Aron GM. Methods of studying biofilms. Microb Biofilms 2004;14:379-413.

9. Michael O. Staphylococcal biofilms. In: Bacterial Biofilms. Heidelberg, Berlin: Springer; 2008. p. 207-28.

10. Turk R, Singh A, Rousseau J, Weese, JS, In vitro evaluation of dispersinb on methicillin-resistant Staphylococcus pseudintermedius Biofilm. Vet Microbiol 2013;166:576-9.

11. Hall-Stoodley L, Costerton JW, Stoodley P. Bacterial biofilms: From the natural environment to infectious diseases. Nat Rev Microbiol 2004;2:95-108.

12. Ponnusamy P, Natarajan V, Sevanan M. In vitro biofilm formation by uropathogenic Escherichia coli and their antimicrobial susceptibility pattern. Asian Pac J Trop Med 2012;5:210-3.

13. Chai FP, Kasing A, Jennifer J, Lesley MB, Lela S, Hashimatul FH. Microtitre plate assay for the quantification of biofilm formation by pathogenic Leptospira. Res J Microbiol 2017;12:146-53.

14. Klaus T, Joerger R, Olsson E, Granqvist CG. Silver-based crystalline nanoparticles, microbially fabricated. Proc Natl Acad Sci USA 1999;96:13611-4.

15. Lowry OH, Rosebrough NJ, Farr AL, Randall RJ. Protein measurement with the folin phenol reagent. J Biol Chem 1951;193:265-75.

16. Stepanović S, Vuković D, Hola V, Bonaventura G, Djukić S, Cirković I, et al. Quantification of biofilm in microtiter plates: Overview of testing conditions and practical recommendations for assessment of biofilm production by staphylococci. APMIS 2007;115:891-9.

17. Shukla SK, Rao TS. Calcium-mediated modulation of staphylococcal bacterial biofilms. Indian J Geomar Sci 2014;43:2107.

18. Mah TF, O'Toole GA. Mechanisms of biofilm resistance to antimicrobial agents. Trends Microbiol 2001;9:34-9.

19. Shakeel A, Mohammad O, Rukhsana S, Anish K. Antibacterial activity of iron oxide nanoparticles synthesized by co-precipitation technology against Bacillus cereus and Klebsiella pneumoniae. Pol J Chem Technol 2017; 19:110-5

20. Prabhu YT, Venkateswara KR, Kumari BS, Sesha SK, Tambur P. Synthesis of $\mathrm{Fe}_{3} \mathrm{O}$ nanoparticles and its antibacterial application. Int Nano Lett 2015;5:85-92.

21. Goswami S, Thiyagarajan D, Das G, Ramesh A. Biocompatible nanocarrier fortified with a dipyridinium-based amphiphile for eradication of biofilm. ACS Appl Mater Interfaces 2014;6:16384-94.

22. Nguyen XT, Pham HL, Ngo TT, Phong XO. Preparation of oral curcumin delivery from 3d-nano-cellulose networks material produced by acetobacter xylinum using optimization technique. Int J Appl Pharm 2020;12:47-52.

23. Hameed IH, Mohammed GJ, Mohammad JA. Secondary Metabolites Analysis of Saccharomyces cerevisiae and evaluation of antibacterial activity. Int J Pharm Clin Res 2016;8:304-15. 